\title{
Cytotoxicity of Ficus Crocata Extract on Cervical Cancer Cells and Protective Effect against Hydrogen Peroxide-Induced Oxidative Stress in HaCaT Non-Tumor Cells
}

\author{
Brenda De la Cruz-Concepción ${ }^{1}$, Mónica Espinoza-Rojo ${ }^{2}\left(\mathbb{D}\right.$, Patricia Álvarez-Fitz ${ }^{3}$, Berenice Illades-Aguiar ${ }^{1}$, \\ Macdiel Acevedo-Quiroz ${ }^{4}$, Ana E. Zacapala-Gómez ${ }^{1}$, Napoleón Navarro-Tito ${ }^{5}{ }^{\mathbb{C}}$, Hilda Jiménez-Wences ${ }^{6}{ }^{\mathbb{D}}$, \\ Francisco I. Torres-Rojas ${ }^{1}$ and Miguel A. Mendoza-Catalán ${ }^{1,6, *(1)}$
}

1 Laboratorio de Biomedicina Molecular, Facultad de Ciencias Químico-Biológicas, Universidad Autónoma de Guerrero, Chilpancingo 39090, Guerrero, Mexico; brenddc@hotmail.com (B.D.1.C.-C.);

billades@uagro.mx (B.I.-A.); zak_ana@yahoo.com.mx (A.E.Z.-G.); trisrael5@yahoo.com.mx (F.I.T.-R.)

2 Laboratorio de Biología Molecular y Genómica, Facultad de Ciencias Químico-Biológicas,

Universidad Autónoma de Guerrero, Chilpancingo 39090, Guerrero, Mexico; moniespinoza@yahoo.com

3 Laboratorio de Toxicología, CONACYT-Universidad Autónoma de Guerrero,

Chilpancingo 39090, Guerrero, Mexico; paty_fitz@hotmail.com

4 Departamento de Química y Bioquímica, Tecnológico Nacional de México, Instituto Tecnológico/IT de Zacatepec, Calzada Tecnológico 27, Centro, Zacatepec 62780, Morelos, Mexico;

check for

updates

Citation: De la Cruz-Concepción, B.; Espinoza-Rojo, M.; Álvarez-Fitz, P.; Illades-Aguiar, B.; Acevedo-Quiroz, M.; Zacapala-Gómez, A.E.; Navarro-Tito, N.; Jiménez-Wences, H.; Torres-Rojas, F.I.; Mendoza-Catalán, M.A. Cytotoxicity of Ficus Crocata Extract on Cervical Cancer Cells and Protective Effect against Hydrogen Peroxide-Induced Oxidative Stress in HaCaT Non-Tumor Cells. Plants 2021, 10, 183. https://doi.org/10.3390/ plants10010183

Academic Editor: Octavian Tudorel Olaru

Received: 10 December 2020

Accepted: 15 January 2021

Published: 19 January 2021

Publisher's Note: MDPI stays neutral with regard to jurisdictional claims in published maps and institutional affiliations.

\section{Copyright: (C) 2021 by the authors.} Licensee MDPI, Basel, Switzerland. This article is an open access article distributed under the terms and conditions of the Creative Commons Attribution (CC BY) license (https:// creativecommons.org/licenses/by/ $4.0 /)$. macdiel.acevedoqui@uaem.mx

5 Laboratorio de Biología Celular del Cáncer, Facultad de Ciencias Químico-Biológicas, Universidad Autónoma de Guerrero, Chilpancingo 39090, Guerrero, Mexico; nnavarro@uagro.mx

6 Laboratorio de Investigación en Biomoléculas, Facultad de Ciencias Químico-Biológicas,

Universidad Autónoma de Guerrero, Chilpancingo 39090, Guerrero, Mexico; wences2009@hotmail.com

* Correspondence: mamendoza@uagro.mx; Tel.: +52-747-4710901

\begin{abstract}
Oxidative stress causes several chronic diseases including cancer. Some chemotherapeutic agents are not selective against tumor cells, causing oxidative stress in non-tumor cells. This study aimed to evaluate the cytotoxic effect of acetone extract of Ficus crocata (Miq.) Mart. ex Miq. (F. crocata) leaves (Ace-EFc) on cervical cancer cells, as well as its protective effect on hydrogen peroxide $\left(\mathrm{H}_{2} \mathrm{O}_{2}\right)$ induced lipoperoxidation and cytotoxicity in non-tumor HaCaT cells. Antioxidant activity was determined using the DPPH and ABTS radicals. Cell viability and lipoperoxidation were determined with MTT and 1-methyl-2-phenylindole assays, respectively. A model of $\mathrm{H}_{2} \mathrm{O}_{2}$-induced cytotoxicity and oxidative damage in $\mathrm{HaCaT}$ cells was established. HaCaT cells were exposed to the extract before or after exposure to $\mathrm{H}_{2} \mathrm{O}_{2}$, and oxidative damage and cell viability were evaluated. Ace-EFc inhibited the DPPH and ABTS radicals and showed a cytotoxic effect on SiHa and HeLa cells. Furthermore, the extract treatment had a protective effect on hydrogen peroxide-induced lipoperoxidation and cytotoxicity, avoiding the increase in MalonDiAldehyde (MDA) levels and the decrease in cell viability $(p<0.001)$. These results suggest that the metabolites of F. crocata leaves possess antioxidant and cytoprotective activity against oxidative damage. Thus, they could be useful for protecting cells from conditions that cause oxidative stress.
\end{abstract}

Keywords: Ficus crocata; Moraceae; antioxidants; hydrogen peroxide; cytoprotective effect; antitumor activity; cervical cancer

\section{Introduction}

The introduction oxidative stress is an imbalance of the redox state generated by the high production of reactive oxygen species (ROS) and the low antioxidant capacity of cells [1]. ROS, such as hydrogen peroxide $\left(\mathrm{H}_{2} \mathrm{O}_{2}\right)$, are constantly produced as a by-product of metabolism and play an important role in cellular homeostasis [2]. However, there are physiological and environmental factors, such as inflammation and exposure to ultraviolet (UV) radiation, that increase their cellular concentrations [3,4]. ROS can react 
with biomolecules and damage their structure and function [5], as well as dysregulate cell metabolism, proliferation, differentiation, and survival in tissues [6].

The overproduction of free radicals is known to cause several chronic degenerative diseases including cancer [7]. Although cells possess antioxidant systems to prevent oxidative damage when there is oxidative stress, the antioxidant system is usually deficient in maintaining ROS levels below the risk threshold. Consequently, the exogenous antioxidants available in food or plants are required to maintain the redox balance in the cell [1,8]. Pharmacological studies have shown that some species of the Ficus genus (Moraceae) exert antioxidant and protective activity against oxidative damage [9-11], and their biological effects have been related to the antioxidant activity of the secondary metabolites present in the plant [12]. Many Ficus species remain scarcely studied, such as Ficus crocata (Miq.) Mart. ex Miq. (F. crocata), one of the most widely distributed Ficus species in Mexico, is used in infusions (bark and leaves) as a traditional medicine for the control of some diseases, such as diabetes and hypertension [13].

The chemotherapeutic agents used in conventional cancer therapy are not selective against tumor cells, causing oxidative stress in non-tumor cells and therefore side effects [14], so the search for selective cytotoxic therapeutics against tumor cells continues. Previously, we reported that the dichloromethane and acetone extract of F. crocata leaves decreased the proliferation capacity of MDA-MB-231 triple-negative breast cancer cells [15]. In this regard, and interestingly, several of the compounds identified in the extracts have been reported as antioxidants; however, their antioxidant activity has not, to our knowledge, been analyzed. This study aimed to evaluate the cytotoxic effect of the acetone extract of F. crocata leaves (Ace-EFc) on cervical cancer SiHa and HeLa cells, as well as the antioxidant activity and the protective effect of the extract on hydrogen peroxide $\left(\mathrm{H}_{2} \mathrm{O}_{2}\right)$-induced lipoperoxidation in non-tumor HaCaT cells.

\section{Results}

\subsection{Ace-EFc Has Antiradical Activity Comparable or Superior to That of Ascorbic Acid}

GC-MS analysis showed the presence of diterpenes, triterpenes, sterols, and tocopherol in the Ace-EFc. Based on abundance, $\alpha$-tocopherol (42.4\%) and squalene (24.0\%) were the major compounds in the extract, followed by stigmastan-3,5-diene (9\%), lupeol $(8.6 \%)$, phytol $(8.5 \%)$, and $\beta$-sitosterol (7.5\%) (Table 1) (Figure S1). Interestingly, Ace-EFc inhibited the $\mathrm{DPPH}^{\bullet}$ and $\mathrm{ABTS}^{\bullet+}$ radicals, demonstrating inhibition activity in both assays compared with the standard ascorbic acid (Figure S2). However, activity was higher on $\mathrm{ABTS}^{\bullet+}\left(\mathrm{IC}_{50}\right.$ of Ace-EFc $=1.47 \pm 1.21 \mu \mathrm{g} / \mathrm{mL}$, and $\mathrm{IC}_{50}$ of $\mathrm{AA}=2.22 \pm 0.80 \mu \mathrm{g} / \mathrm{mL}$, $p<0.05)$ than on the $\mathrm{DPPH}^{\bullet}$ radical $\left(\mathrm{IC}_{50}\right.$ of $\mathrm{EAFC}=107.05 \pm 2.61 \mu \mathrm{g} / \mathrm{mL}$, and $\mathrm{IC}_{50}$ of $\mathrm{AA}=118.82 \pm 2.48 \mu \mathrm{g} / \mathrm{mL}, p<0.05)$ (Table 2).

Table 1. The chemical composition of acetone extract from F. crocata (Ace-EFc).

\begin{tabular}{ccccccc}
\hline No. & Compound & $\begin{array}{c}\text { PubChem } \\
\text { CID }\end{array}$ & Family & $\begin{array}{c}\text { Molecular } \\
\text { Formula }\end{array}$ & $\begin{array}{c}\text { Molecular } \\
\text { Weight }\end{array}$ & $\begin{array}{c}\text { Abundance } \\
(\%)\end{array}$ \\
\hline 1 & Phytol & 5366244 & Diterpene & $\mathrm{C}_{20} \mathrm{H}_{40} \mathrm{O}$ & 296.539 & 8.50 \\
2 & Squalene & 638072 & Triterpene & $\mathrm{C}_{30} \mathrm{H}_{50}$ & 410.73 & 24.00 \\
3 & Stigmastan-3,5-diene & 525918 & Sterol & $\mathrm{C}_{29} \mathrm{H}_{48}$ & 396.703 & 9.00 \\
4 & Alpha-tocopherol & 14985 & Tocopherol & $\mathrm{C}_{29} \mathrm{H}_{50} \mathrm{O}_{2}$ & 430.717 & 42.40 \\
5 & B-sitosterol & 222284 & Sterol & $\mathrm{C}_{29} \mathrm{H}_{50} \mathrm{O}$ & 414.718 & 7.50 \\
6 & Lupeol & 259846 & Triterpene & $\mathrm{C}_{30} \mathrm{H}_{50} \mathrm{O}$ & 426.729 & 8.60 \\
\hline * Percentage of the total, considering the compounds identified in GC-MS analysis.
\end{tabular}

* Percentage of the total, considering the compounds identified in GC-MS analysis.

Table 2. $\mathrm{IC}_{50}$ for DPPH and ABTS free radical scavenging activity of Ace-EFc.

\begin{tabular}{ccc}
\hline Samples & \multicolumn{2}{c}{$\mathrm{IC}_{\mathbf{5 0}}(\mu \mathrm{g} / \mathrm{mL}) \pm \mathrm{SD}$} \\
\hline & $\mathrm{DPPH}$ & ABTS \\
Ace-EFc & $107.05 \pm 2.61^{*}$ & $1.47 \pm 1.21^{*}$ \\
Ascorbic Acid & $118.82 \pm 2.48$ & $2.22 \pm 0.80$ \\
\hline
\end{tabular}

Samples were analyzed using $t$ test: ${ }^{*} p<0.05$ versus ascorbic acid. DPPH $=2,2$-Diphenyl-1-picrylhydrazyl; $\mathrm{ABTS}=2,2^{\prime}$-azinobis-(3-ethylbenzothiazoline-6-sulfonic acid); $\mathrm{SD}=$ standard deviation. 


\subsection{Ace-EFc Is Cytotoxic on SiHa and HeLa Cervical Cancer Cells But Not in HaCaT Non-Tumor Cells}

$\mathrm{HaCaT}, \mathrm{SiHa}$, and HeLa cells were exposed to different Ace-EFc concentrations $(0-320 \mu \mathrm{g} / \mathrm{mL})$ and cell viability was determined. Exposure to Ace-EFc induced a concentration-dependent cytotoxic effect ( $<80 \%$ viable cells) from 40 to $320 \mu \mathrm{g} / \mathrm{mL}$ and from 5 to $40 \mu \mathrm{g} / \mathrm{mL}$ in SiHa and HeLa cells, respectively (Figure 1); In HeLa cells, the percentage of viable cells recovered at concentrations greater than $80 \mu \mathrm{g} / \mathrm{mL}$, however, the number of viable cells remained below $80 \%$. In contrast, in $\mathrm{HaCaT}$ cells, no changes were observed compared with the control at $1.25-20 \mu \mathrm{g} / \mathrm{mL}$, and the Ace-EFc concentrations of $40-320 \mu \mathrm{g} / \mathrm{mL}$ decreased cell viability compared to control $(p<0.001)$. Nevertheless, the percent of viable cells remained above $80 \%$ under all conditions. Thus, it is concluded that Ace-EFc does not exert a cytotoxic effect on $\mathrm{HaCaT}$ cells (Figure 1). Ace-EFc showed a greater cytotoxic effect on SiHa cells $\left(\mathrm{IC}_{50}=196.99 \pm 2.70 \mu \mathrm{g} / \mathrm{mL}, p<0.001\right)$ followed by HeLa cells $\left(\mathrm{IC}_{50}=463.30 \pm 3.23 \mu \mathrm{g} / \mathrm{mL}\right.$, $p<0.01$ ) compared to HaCaT cells $\left(\mathrm{IC}_{50}=734.33 \pm 2.20 \mu \mathrm{g} / \mathrm{mL}\right.$ ) (Table 3). Considering these observations, the concentrations of $1.25-20 \mu \mathrm{g} / \mathrm{mL}$ were considered to evaluate the antioxidant activity of Ace-EFc on $\mathrm{HaCaT}$ cells.
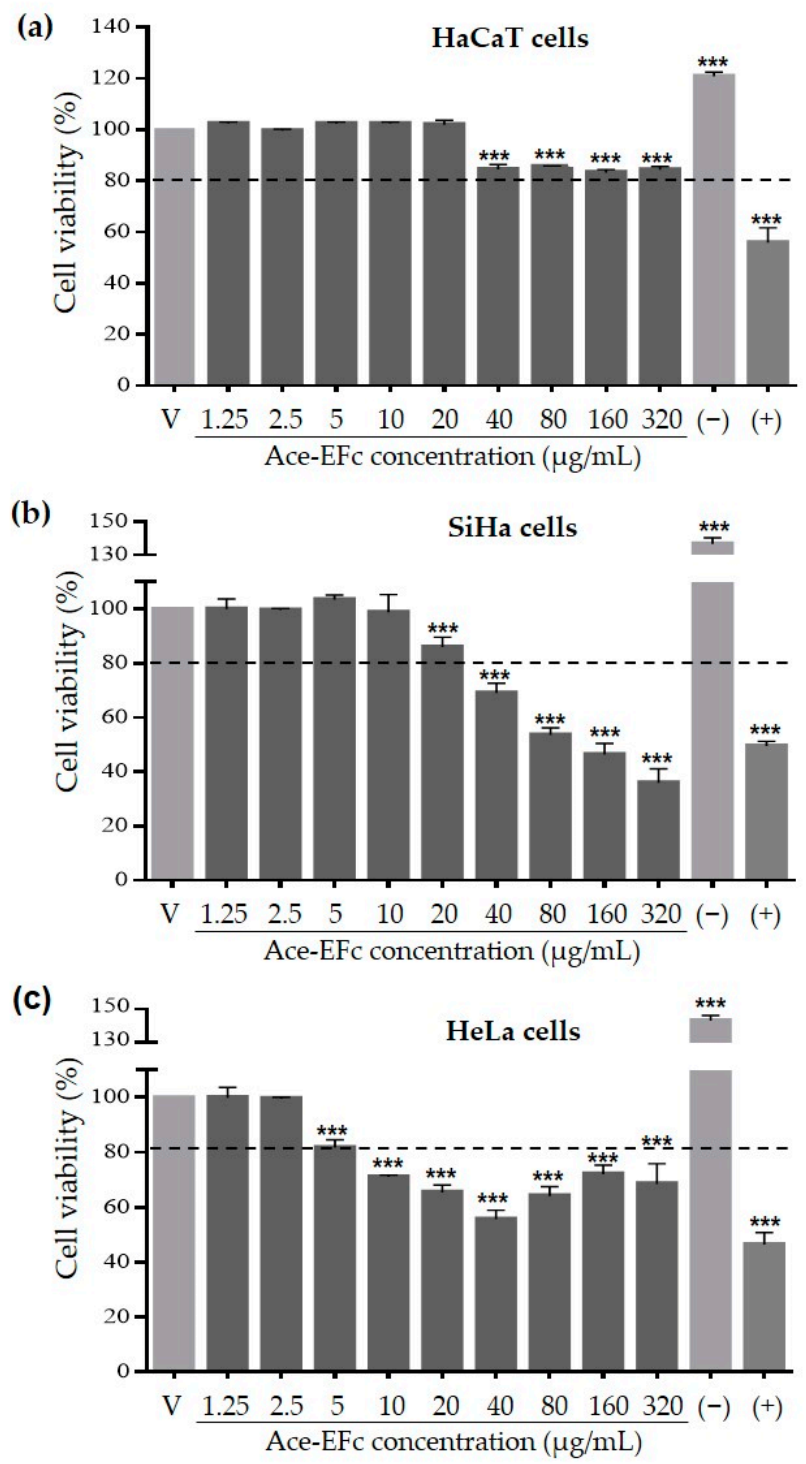

Figure 1. Effect of acetone extract from F. crocata (Ace-EFc) on cell viability. HaCaT, SiHa, and HeLa cells were treated with 0-320 $\mathrm{\mu g} / \mathrm{mL}$ of Ace-EFc for $24 \mathrm{~h}$. MTT assay for (a) $\mathrm{HaCaT}$, (b) SiHa, and (c) HeLa cells. V: vehicle, cells treated with diluent of the extracts (DMSO $<1 \%) ;(-)$ : negative control, $10 \%$ FBS. (+): Positive control, $100 \mu \mathrm{M}$ Ara-C (cytarabine). Results were expressed as the mean $\pm \mathrm{SD}$ of three independent experiments. One-way ANOVA, Dunnett's test: ${ }^{* * *} p<0.001$ versus C. 
Table 3. $\mathrm{IC}_{50}$ of Ace-EFc on the viability of HaCaT, SiHa, and HeLa cells.

\begin{tabular}{cc}
\hline Cell Line & IC $_{50}(\mu \mathrm{g} / \mathrm{mL}) \pm \mathrm{SD}$ \\
\hline HaCaT & $734.33 \pm 2.20$ \\
$\mathrm{SiHa}$ & $196.99 \pm 2.70^{* * *}$ \\
$\mathrm{HeLa}$ & $463.30 \pm 3.23^{* *}$
\end{tabular}

Samples were analyzed using $t$ test. ${ }^{* *} p<0.01,{ }^{* * *} p<0.001$ compared to HaCaT cells. Ace-EFc $=$ acetone extract from Ficus crocata, $\mathrm{SD}=$ standard deviation.

$\mathrm{HaCaT}$ cells were exposed to different concentrations $(200-1000 \mu \mathrm{M})$ and exposure times $(0.5-4 \mathrm{~h})$ of $\mathrm{H}_{2} \mathrm{O}_{2}$ to establish the concentrations that induce cytotoxicity and oxidative damage in this cell model. Cytotoxicity and increased lipoperoxidation were observed at $1000 \mu \mathrm{M} \mathrm{H}_{2} \mathrm{O}_{2}$ for $2 \mathrm{~h}$; under these conditions, MDA levels increased 700\% compared to the control $(p<0.0001)$ (Figure $2 \mathrm{a})$, and the percent of viable cells was reduced to $69 \%$ $(p<0.0001)$ (Figure 2b).

(a)

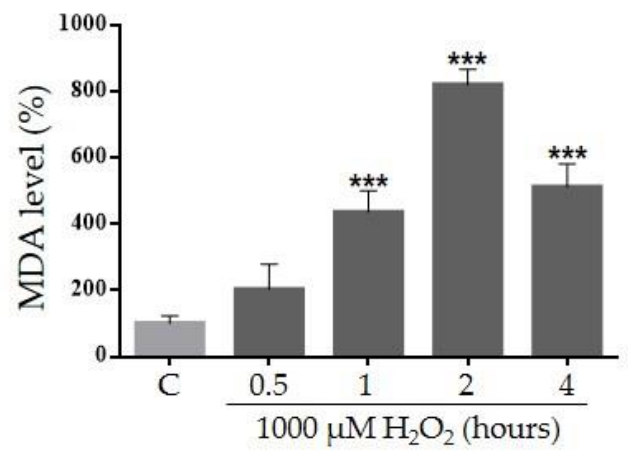

(b)
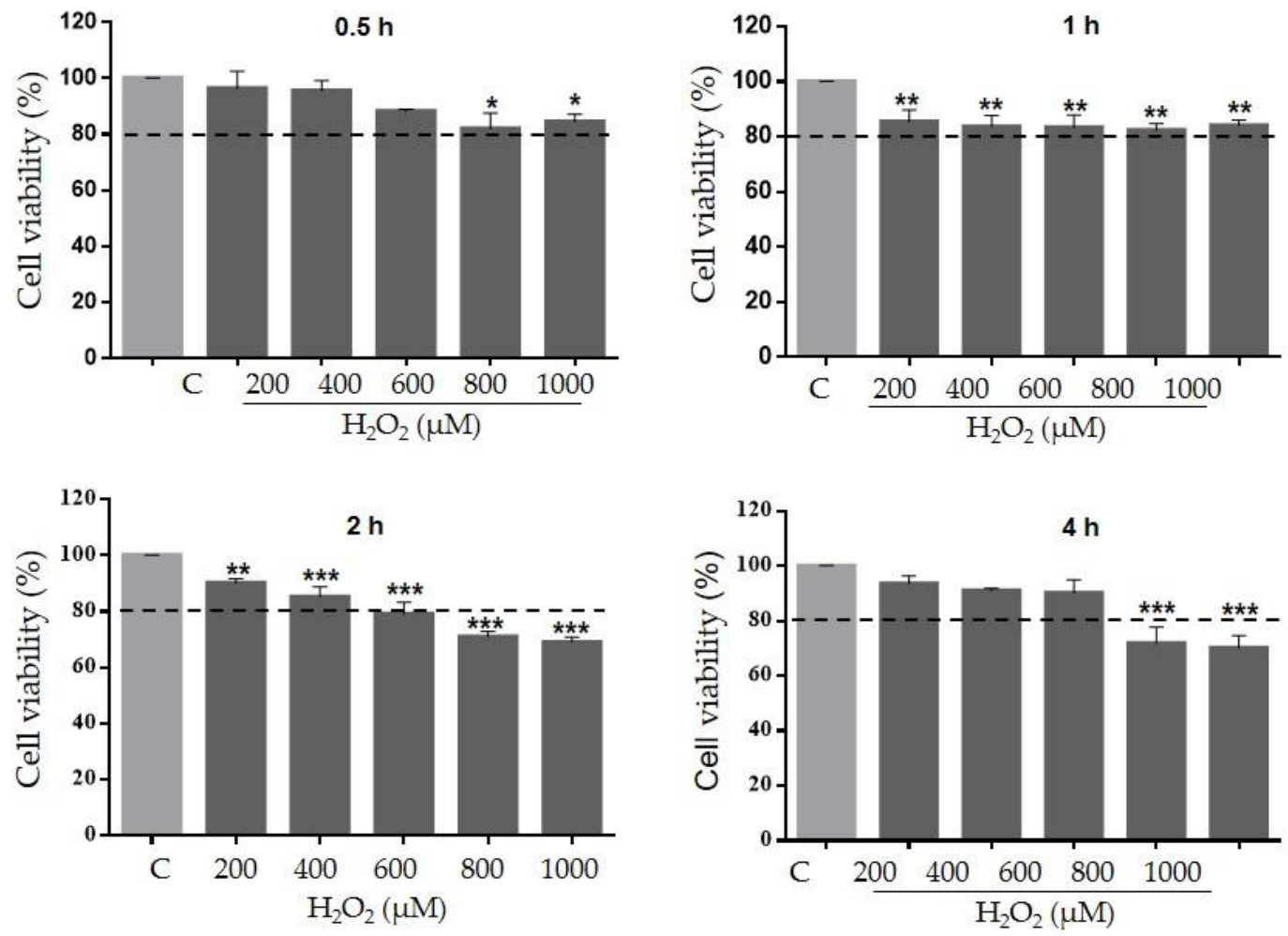

Figure 2. Establishment of $\mathrm{H}_{2} \mathrm{O}_{2}$-induced oxidative damage and cytotoxicity model on HaCaT cells. (a) Quantification of MDA levels to the determination of $\mathrm{H}_{2} \mathrm{O}_{2}$-induced lipoperoxidation. HaCaT cells were treated with $1000 \mu \mathrm{M} \mathrm{H}_{2} \mathrm{O}_{2}$ for $0.5,1,2$, or $4 \mathrm{~h}$. (b) MTT assay to the determination of $\mathrm{H}_{2} \mathrm{O}_{2}$-induced cytotoxicity. $\mathrm{HaCaT}$ cells were treated with $\mathrm{H}_{2} \mathrm{O}_{2}$ $(200-1000 \mu \mathrm{M})$ for $0.5,1,2$, or $4 \mathrm{~h}$. Results were expressed as the mean $\pm \mathrm{SD}$ of three independent experiments. One-way ANOVA, Dunnett's test: ${ }^{*} p<0.05,{ }^{* *} p<0.01,{ }^{* * *} p<0.001$ versus C. 


\subsection{Ace-EFc Protects HaCaT Cells from $\mathrm{H}_{2} \mathrm{O}_{2}$-Induced Lipoperoxidation and Cytotoxicity}

To assess the preventive effect of Ace-EFc on $\mathrm{H}_{2} \mathrm{O}_{2}$-induced oxidative damage, Ha$\mathrm{CaT}$ cells were pretreated with Ace-EFc for $24 \mathrm{~h}$ and were subsequently treated with $1000 \mu \mathrm{M} \mathrm{H}_{2} \mathrm{O}_{2}$ for $2 \mathrm{~h}$. Interestingly, Ace-EFc pretreatment prevented lipoperoxidation in a concentration-dependent manner compared to cells treated with $\mathrm{H}_{2} \mathrm{O}_{2}$ alone $(p<0.0001)$. Concentrations of $1.25,2.5,5,10$, and $20 \mu \mathrm{g} / \mathrm{mL}$ of EAFC reduced the formation of MDA $9.9,7.3,15.2,25.1$, and 143.5 times, respectively, compared to the group treated with $\mathrm{H}_{2} \mathrm{O}_{2}$, which increased MDA formation 8.2 times compared to the control $(p<0.0001)$ (Figure 3). No statistical differences at the MDA level were observed in the cells treated with Ace-EFc compared to the untreated cells. However, a tendency to decrease in a concentration-dependent manner from $5 \mu \mathrm{g} / \mathrm{mL}$ was observed (Figure 3).

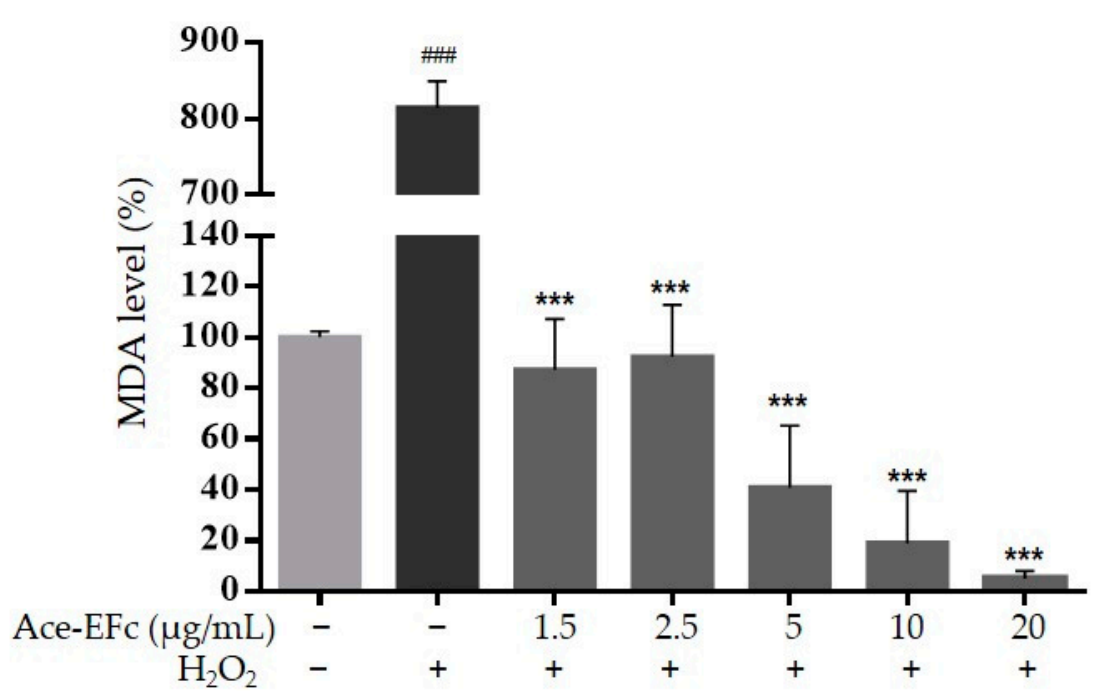

Figure 3. Protective effect of Ace-EFc against $\mathrm{H}_{2} \mathrm{O}_{2}$-induced lipoperoxidation. HaCaT cells were pretreated with Ace-EFc $(1.25,2.5,5,10$, and $20 \mu \mathrm{g} / \mathrm{mL})$ for $24 \mathrm{~h}$, and later, treated with $1000 \mu \mathrm{M}$ $\mathrm{H}_{2} \mathrm{O}_{2}$ for $2 \mathrm{~h}$. Results were expressed as the mean $\pm \mathrm{SD}$ of three independent experiments. Oneway ANOVA, Dunnett's test: ${ }^{\# \# \#} p<0.001$ versus no treated cells, ${ }^{* * *} p<0.001$ versus treated cells with $\mathrm{H}_{2} \mathrm{O}_{2}$.

To assess the preventive effect of Ace-EFc on $\mathrm{H}_{2} \mathrm{O}_{2}$-induced cytotoxicity, $\mathrm{HaCaT}$ cells were pretreated with Ace-EFc for $24 \mathrm{~h}$ and subsequently were treated with $1000 \mu \mathrm{M} \mathrm{H}_{2} \mathrm{O}_{2}$ for $2 \mathrm{~h}$. Ace-EFc exhibited a protective effect against $\mathrm{H}_{2} \mathrm{O}_{2}$-induced cytotoxicity. Previous exposure to concentrations of 1.25, 2.5, 5, 10, and $20 \mu \mathrm{g} / \mathrm{mL}$ of Ace-EFc maintained cell viability at $94.9 \%, 93.7 \%, 94.9 \%, 92.7 \%$, and $83.1 \%$, respectively, even after $\mathrm{H}_{2} \mathrm{O}_{2}$ treatment, whereas when cells were treated with $\mathrm{H}_{2} \mathrm{O}_{2}$ alone, $69 \%$ of viable cells were observed $(p<0.001)$ (Figure 4a). Moreover, $\mathrm{H}_{2} \mathrm{O}_{2}$ treatment induced morphological cell changes, such as apparent damage to the cell membrane and a reduction in size and vesiculation in some cells, which could be associated with cell death. However, pretreatment with Ace-EFc avoided these cellular changes, and even cells treated with $\mathrm{H}_{2} \mathrm{O}_{2}$ retained a similar morphology to untreated cells (Figure $4 b$ ).

Taken together, these observations suggest that the compounds present in Ace-EFc have a selective cytotoxic effect against cervical tumor cells, without affecting non-tumor cells, in which the compounds could behave as antioxidants, even providing a cytoprotective effect against oxidative molecules. 


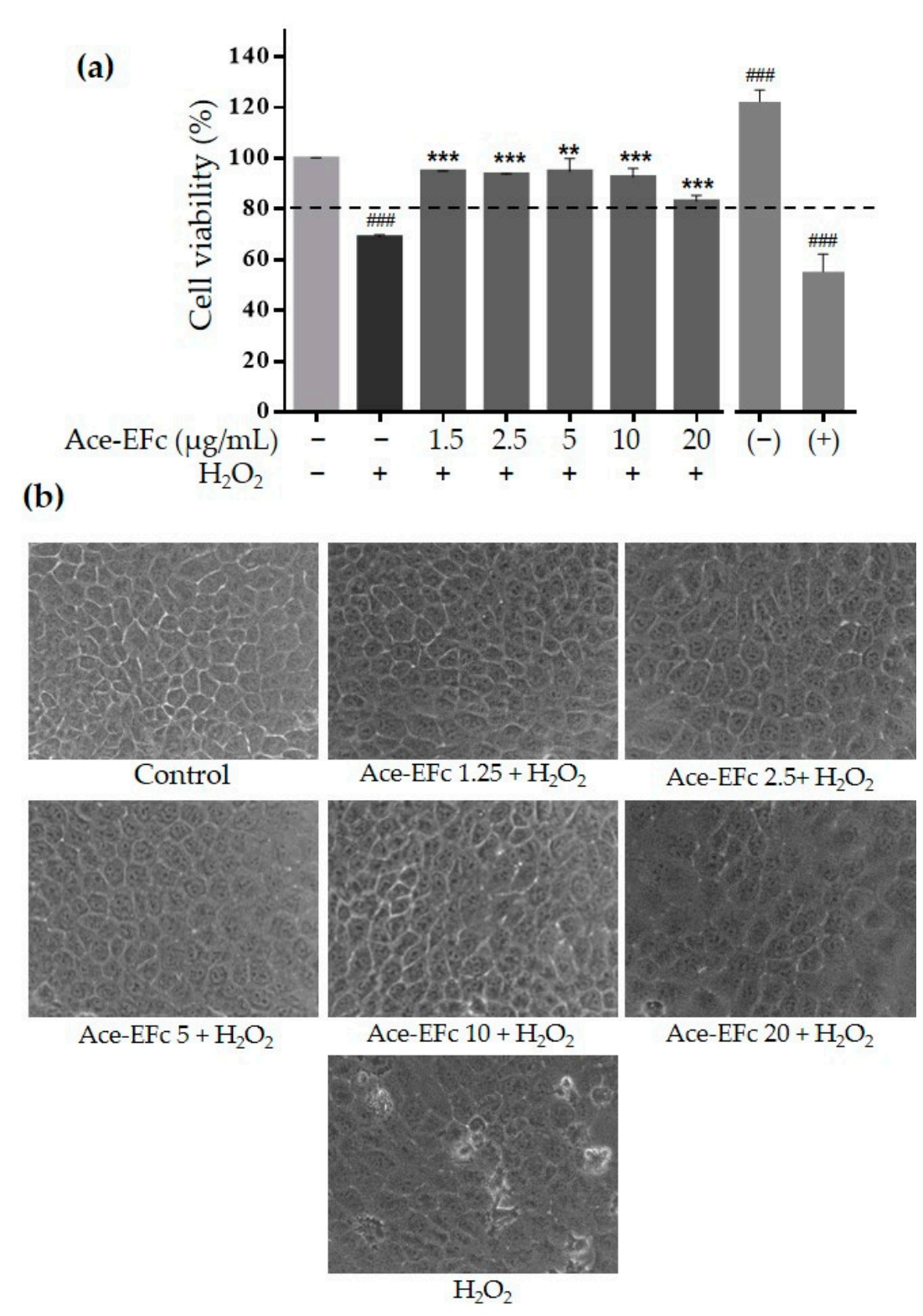

Figure 4. Protective effect of Ace-EFc against $\mathrm{H}_{2} \mathrm{O}_{2}$-induced cytotoxicity. HaCaT cells were pretreated with Ace-EFc $(1.25,2.5,5,10$, and $20 \mu \mathrm{g} / \mathrm{mL})$ for $24 \mathrm{~h}$ before treatment with $1000 \mu \mathrm{M} \mathrm{H}_{2} \mathrm{O}_{2}$ for $2 \mathrm{~h}$. (a) MTT assays. (-): negative control, cells stimulated with $10 \%$ FBS. (+). Positive control, $100 \mu \mathrm{M}$ Ara-C (cytarabine). Results were expressed as the mean \pm SD of three independent experiments. One-way ANOVA, Dunnett's test: ${ }^{\# \#} p<0.001$ versus no treated cells; ${ }^{* *} p<0.01,{ }^{* * *} p<0.001$ versus treated cells with $\mathrm{H}_{2} \mathrm{O}_{2}$. (b) Micrographs of $\mathrm{HaCaT}$ cells from (a).

\section{Discussion}

The overproduction of free radicals is known to cause several chronic degenerative diseases including cancer; however, some therapeutic molecules increase the production of free radicals to induce the death of tumor cells $[7,16]$. Moreover, the chemotherapeutic agents used in conventional cancer therapy are not selective against tumor cells, causing oxidative stress in non-tumor cells and therefore side effects affecting the health of patients [14]. So, it is necessary to find compounds with selective cytotoxic activity against tumor cells. In this regard, some compounds such as curcumin, have been reported to show a prooxidant effect in tumor cells inducing cell death, while they show an antioxidant effect in non-tumor cells [16]. Here, we reported the cytotoxic effect of acetone extract of Ficus crocata on cervical tumor $\mathrm{SiHa}$ and HeLa cells (Figure 1), while in non-tumor cells $\mathrm{HaCaT}$ the extract showed a protective effect against $\mathrm{H}_{2} \mathrm{O}_{2}$-induced lipoperoxidation and 
cytotoxicity (Figures 3 and 4). Considering the above, the compounds present in Ace-EFC act as antioxidants in the $\mathrm{HaCaT}$ non-tumor cells and probably they have a prooxidant effect in the HeLa and SiHa cervical cancer cells.

We observed that Ace-EFc inhibited DPPH ${ }^{\bullet}$ and $\mathrm{ABTS}^{\bullet+}$ radicals, however, the activity was higher on $\mathrm{ABTS}^{\bullet+}$ than on the $\mathrm{DPPH}^{\bullet}$ radical (Table 2). It is reported that some extracts with inhibitory activity on the $\mathrm{ABTS}^{\bullet+}$ radical did not exhibit inhibitory activity on the $\mathrm{DPPH}^{\bullet}$ radical, due to the fact that $\mathrm{ABTS}^{\bullet+}$ reacts energetically with electrons and has less selectivity in the reaction with atom hydrogen donors [17]. In contrast, the DPPH ${ }^{\bullet}$ radical is more selective than $\mathrm{ABTS}^{\bullet+}$ in the reaction with hydrogen donors and does not react with aromatic acids containing only one $\mathrm{OH}$ group [18]. This suggests that the antioxidant activity of Ace-EFc by inhibiting $\mathrm{DPPH}^{\bullet}$ and $\mathrm{ABTS}^{\bullet+}$ radicals is due to the presence and synergistic activity of compounds that participate in both the donation of hydrogen atoms and electrons, such as tocopherols, triterpenes, diterpenes, and phytosterols, which are recognized as antioxidants because of their ability to capture free radicals $[5,19,20]$.

To evaluate the antioxidant activity of Ace-EFc, we first established a model of $\mathrm{H}_{2} \mathrm{O}_{2}$ induced cytotoxicity and oxidative damage in $\mathrm{HaCaT}$ cells; cytotoxicity and increased lipoperoxidation were observed at $1000 \mu \mathrm{M} \mathrm{H}_{2} \mathrm{O}_{2}$ for $2 \mathrm{~h}$ (Figure 2). Apparently, $\mathrm{H}_{2} \mathrm{O}_{2}$ was converted into $\mathrm{OH}^{\bullet}$ radicals in the presence of $\mathrm{Fe}^{2+}$ through the Fenton reaction within the cell [21], altering intracellular macromolecules such as the polyunsaturated fatty acids of the membranes, in that they are the main targets of ROS, causing lipid peroxidation [22]. This could explain the induction of lipoperoxidation at a short exposure time with $\mathrm{H}_{2} \mathrm{O}_{2}(2 \mathrm{~h})$ observed in Figure $2 \mathrm{a}$, and, also in terms of causing lipoperoxidation, high concentrations of ROS can damage other macromolecules such as DNA and proteins, giving rise to oxidative damage in organelles and consequently, cell death $[5,23]$.

The cytotoxic effect of $\mathrm{H}_{2} \mathrm{O}_{2}$ on $\mathrm{HaCaT}$ cells was in agreement with that previously reported, and the reduction in cell viability corresponds to the oxidative damage caused by the increase in $\mathrm{H}_{2} \mathrm{O}_{2}$ concentration [20,23-25]. Considering that mitochondrial homeostasis plays a key role in cell viability and survival [26], the cytotoxic effect has been associated with mitochondrial dysfunction and $\mathrm{H}_{2} \mathrm{O}_{2}$-induced apoptotic events [20,23-25]. Properly functioning mitochondria produce ATP and modulate cellular redox balance to ensure cell metabolism $[27,28]$. However, damaged mitochondria participate in apoptotic signal activation and amplification through multiple effects [29]. $\mathrm{H}_{2} \mathrm{O}_{2}$-induced oxidative damage in $\mathrm{HaCaT}$ cells has been reported to induce mitochondrial dysfunction by increasing concentrations of ROS, decreasing antioxidant defenses (SOD, GPx, and GSH), and increasing the release of cytochrome $\mathrm{C}$ into the cytoplasm and nucleus [24]. On the other hand, exposure to $\mathrm{H}_{2} \mathrm{O}_{2}$ is known to promote apoptosis, because it increases the expression and activation of pro-apoptotic proteins, such as Bax and caspases 3, 6, 7, 8, and 9, and reduces the expression of the anti-apoptotic protein Bcl-2 $[21,24,25]$. These events could explain the $\mathrm{H}_{2} \mathrm{O}_{2}$-induced oxidative damage and cytotoxicity in $\mathrm{HaCaT}$ cells.

To assess the preventive effect of Ace- $\mathrm{EFc}$ on $\mathrm{H}_{2} \mathrm{O}_{2}$-induced oxidative damage, $\mathrm{HaCaT}$ cells were pretreated with Ace-EFc for $24 \mathrm{~h}$ and were subsequently treated with $\mathrm{H}_{2} \mathrm{O}_{2}$. We observed that Ace-EFc pretreatment prevented $\mathrm{H}_{2} \mathrm{O}_{2}$-induced lipoperoxidation in a concentration-dependent manner. The compounds identified in the Ace-EFc (diterpenes, triterpenes, sterols, and tocopherols) have been recognized as antioxidants due to their ability to scavenge free radicals. Thus, they are capable of regulating their concentration, preventing the morphological alterations and oxidative damage caused by oxidative stress inducers $[5,19,20]$. Triterpenes and diterpenes have been shown to sequester and decrease $\mathrm{OH}^{\bullet}$ production, respectively. Triterpenes have greater reducing power than endogenous glutathione (GSH) and possess strong uptake activity against $\mathrm{O}_{2}{ }^{-{ }^{-}}$and its metabolites [30]. On the other hand, phytosterols and tocopherols reduce $\mathrm{H}_{2} \mathrm{O}_{2}$ through the donation of a hydrogen atom $[19,24]$, which demonstrates the high antioxidant capacity of these phytochemicals in reducing free radicals. It is suggested that the compounds present in the Ace-EFc regulated ROS concentrations in the cells and potentiated the expression and activity of endogenous antioxidants. This is because tocopherols, triterpenes, diterpenes, 
and phytosterols have been demonstrated to regulate the concentration and activity of GSH, GPx, GSTM1, GR, SOD, and CAT. Moreover, these compounds prevent oxidative damage in macromolecules, preventing lipoperoxidation, therefore reducing MDA levels [5,31-34], which is consistent with the results in the present study. $\alpha$-Tocopherol was the major compound identified in the Ace-EFc (Table 1). Tocopherols are important antioxidants for cell protection. The presence of these compounds in the cell can influence the decrease in oxidative stress, thus preventing the oxidation of polyunsaturated fatty acids in cell membranes $[35,36]$. The activity of tocopherols has been attributed to their lipophilic nature, which facilitates their free distribution in and action on the membrane, favoring the elimination of lipoperoxides [37], which could explain the reduction in MDA when the cells were treated with Ace-EFc.

On the other hand, we observed that Ace-EFc exhibited a protective effect against $\mathrm{H}_{2} \mathrm{O}_{2}$-induced cytotoxicity on $\mathrm{HaCaT}$ cells. These results are consistent with several studies in which the cytoprotective activity of the compounds identified in Ace-EFc was reported against the toxicity of oxidative stress inducers. It is reported that tocopherols and triterpenes possess neuroprotective [20,38], hepatoprotective [5,34], cardioprotective [39], and cytoprotective activity on sperm [40] and testicular morphological alterations [33] in rats and mice. Specifically, $\alpha$-tocopherol showed to reduce ROS levels in HaCaT cells exposed to UV light, thereby increasing the cell viability altered by this oxidative stress inducer [41] Furthermore, tocopherols increase the survival rate in renal epithelial cells exposed to oxidative stress, as they prevent the depolarization of the mitochondrial membrane by decreasing $\mathrm{H}_{2} \mathrm{O}_{2}$ levels, also decreasing caspase-3 levels [42]. Triterpenes, in addition to preventing lipoperoxidation, avoid protein carbonylation, and protect the permeability of the mitochondrial membrane by avoiding the decrease of Bcl-2 and the increase of Bax, important regulators of the apoptotic cascade. Triterpenes also decrease the release of cytochrome $C$ and the level of caspases $9 / 3$ and, inhibit DNA damage by reducing the formation of $8-\mathrm{OH}-\mathrm{dG}$ and DNA fragmentation $[5,34,43]$. On the other hand, exposure to tocopherols has also resulted in significant protection against damage to the cell membrane [35], which is consistent with the observation that Ace-EFc prevents $\mathrm{H}_{2} \mathrm{O}_{2}$-caused damage on the membrane and cell morphology.

Taken together, the data suggest that the compounds present in Ace-EFc possess antioxidant activity and protect cells from oxidative damage, regulating the antioxidant system of cells and trapping the free radicals generated by the inducers of oxidative stress. However, further studies are required to delve deeper into the mechanism of action that Ace-EFc compounds employ to protect cells from the different inducers of oxidative damage. This study provides, to our knowledge for the first time, information on the antioxidant capacity of the leaf extracts of F. crocata in a non-tumor cell model. Previously, we demonstrated that these extracts revealed antiproliferative activity in MDA-MB-231 breast cancer cells, inducing cell cycle arrest and apoptosis [15], which highlights the importance of continuing to study the effect of these compounds, their potential use as antioxidants in non-tumor cells, and as antiproliferative agents in tumor cells.

In conclusion, the acetone leaf extract of $F$. crocata showed selective cytotoxic activity against $\mathrm{SiHa}$ and HeLa cervical cancer cells, without affecting HaCaT non-tumor cells. More studies are required to analyze the mechanisms by which the compounds identified in the extract induce cytotoxicity in cervical tumor cells. Besides, the acetone leaf extract of $F$. crocata has antioxidant activity comparable or superior to that of ascorbic acid, due to its containing compounds with antioxidant activity, such as $\alpha$-tocopherol, squalene, stigmastan-3,5-diene, lupeol, phytol, and $\beta$-sitosterol, in order of abundance, and prevents $\mathrm{H}_{2} \mathrm{O}_{2}$-induced lipoperoxidation and cytotoxicity in $\mathrm{HaCaT}$ cells.

\section{Materials and Methods}

\subsection{Plant Material and Preparation of the Extract}

Leaves of Ficus crocata (Miq.) Mart. ex Miq. were collected from Petaquillas, Guerrero, Mexico $\left(17^{\circ} 29^{\prime} 15^{\prime \prime} \mathrm{N}\right.$ and $\left.99^{\circ} 27^{\prime} 35^{\prime \prime} \mathrm{W}\right)$ and authenticated in agreement with that previously 
described by Sánchez-Valdeolivar et al. [15], a specimen of the plant is deposited at Herbario Nacional de México (MEXU), voucher number MEXU:1100067. The samples (100 g) were cleaned, dried for over 8 days at $39{ }^{\circ} \mathrm{C}$ protected from light, and then pulverized. The powder was macerated with acetone solvent (reactive-grade, $500 \mathrm{~mL}$, during $24 \mathrm{~h}$, three times). The macerated material was filtered, and the organic phase was evaporated in a rotary evaporator (Digital Rotary Evaporator Model 410, Puebla, México) at $60{ }^{\circ} \mathrm{C}$ and $80 \mathrm{rpm}$. The acetone extracts were stored at $-20^{\circ} \mathrm{C}$ and protected from light until their use.

\subsection{Phytochemical Profile of Ace-EFc}

The volatile compounds present in the Ace-EFc were identified by Gas Chromatography-Mass spectrometry (GC-MS) analysis. The analyses were carried out in triplicate in an Agilent 6890 series Gas Chromatograph equipped with a mass selective detector (5973N, Santa Clara, CA, USA). The experimental conditions of the GC-MS system were the following: HP-5MS capillary nonpolar column (30 m; ID: $0.20 \mathrm{~mm}$; film thickness: $0.25 \mu \mathrm{m})$. The carrier gas was helium at a flow rate of $1.0 \mathrm{~mL} / \mathrm{min}$. Concerning the gas chromatography, the temperature program (oven temperature) was $50^{\circ} \mathrm{C}$, raised to $230^{\circ} \mathrm{C}$ at $2{ }^{\circ} \mathrm{C} / \mathrm{min}$, and the injection volume was $1 \mu \mathrm{L}$ [15]. All results were compared by utilizing the NIST/EPA/NIH Mass Spectral library version 1.7a (ChemStation, Santa Clara, CA, USA).

\section{3. $\mathrm{DPPH}^{\bullet}$ and $A B T S^{\bullet+}$ Radical Inhibition Assays}

To evaluate the antiradical activity of Ace-EFc, $0.05-200 \mu \mathrm{g} / \mathrm{mL}$ of Ace-EFc was placed in 96-well plates (Corning, NY, USA), and $150 \mu \mathrm{L}$ of $0.3 \mathrm{mM}$ 2,2-DiOhenyl-1-PicrylHydrazyl $\left(\mathrm{DPPH}^{\bullet}\right)$ or 2,2' -AzinoBis-(3-ethylbenzoThiazoline-6-Sulfonic acid) $\left(\mathrm{ABTS}^{\bullet+}\right)$ radicals were added $[44,45]$. Previously, the ABTS ${ }^{\bullet+}$ reagent was produced by reacting the ABTS solution $(7 \mathrm{mM})$ with potassium persulfate $[2.45 \mathrm{mM}]$. After incubation for $16 \mathrm{~h}$ at room temperature, $1 \mathrm{~mL}$ of this solution was diluted in $60 \mathrm{~mL}$ of methanol. In both tests, methanol was employed as blank, while ascorbic acid $(0.05-200 \mu \mathrm{g} / \mathrm{mL})$ was used as standard antioxidant. The reactions between Ace-EFc and $\mathrm{DPPH}^{\bullet}$ or $\mathrm{ABTS}^{\bullet+}$ were incubated in the dark at room temperature for $30 \mathrm{~min}$, then read at $545 \mathrm{~nm}$ (Star Fax 2100, Awareness Technologies, Palm city, FL, USA) and $734 \mathrm{~nm}$ (Multiskan FC Plate Leader, LabSystems, Waltham, MA, USA), respectively. The half-maximal Inhibitory Concentration $\left(\mathrm{IC}_{50}\right)$ was calculated through the linear equation $(Y=m X+b)$ using GraphPad Prism v6.0 software. The percentage of radical inhibition was determined by the following formula:

$$
\% \text { inhibition }=\left(1-\left(\frac{\mathrm{A} b \text { Sample }}{\mathrm{A} b \text { Blank }}\right) \times 100\right.
$$

\subsection{Cell Culture and $\mathrm{H}_{2} \mathrm{O}_{2}$-Induced Lipoperoxidation and Cytotoxicity Model}

$\mathrm{HaCaT}, \mathrm{SiHa}$, and HeLa cell lines were obtained and previously certified from Instituto Nacional de Cancerología (CDMX, Mexico). HaCaT, SiHa, and HeLa cells were cultured in Dulbecco's Modified Eagle's Medium formula 12 (DMEM/F12) supplemented with 10\% Fetal Bovine Serum (FBS), $1 \%$ antibiotic (Ampicillin/Streptomycin), and incubated at $37^{\circ} \mathrm{C}$ in a $5 \% \mathrm{CO}_{2}$ atmosphere at $95 \%$ humidity and were grown to $80 \%$ confluence. To establish $\mathrm{H}_{2} \mathrm{O}_{2}$ concentrations inducing cytotoxicity and oxidative damage, the $\mathrm{HaCaT}$ cells were exposed to $0,200,400,600,800$, and $1000 \mu \mathrm{M}$ of $\mathrm{H}_{2} \mathrm{O}_{2}$ during $0.5,1,2$, and $4 \mathrm{~h}$, and cell viability and lipoperoxidation were determined.

\subsection{Cell Viability Assays}

Cell viability was evaluated using the MTT [3-(4,5-dimethylthiazol-2-yl)-2,5-diphenyltetrazolium bromide] cell proliferation colorimetric assay (CT02, Millipore Corp., Bedford, MA, USA) according to the manufacturer's instructions. Briefly, in a 96-well plate, $1 \times 10^{4} \mathrm{HaCaT}$, SiHa, or HeLa cells per well were cultured with DMEM/F12 medium with $10 \% \mathrm{FBS}$ for $24 \mathrm{~h}$. The cells were treated with $0-320 \mu \mathrm{g} / \mathrm{mL}$ of Ace-EFc for $24 \mathrm{~h}$. After the treatment, the medium containing the extract was replaced by fresh basal medium and 
$100 \mu \mathrm{L}$ of the MTT reagent was added for $4 \mathrm{~h}$. The formazan crystals were diluted with Isopropanol, and the Optical Density (OD) of the supernatant was obtained at a wavelength of 545/630 nm (Star Fax 2100, Awareness Technologies, Palm city, FL, USA). To assess the protective effect of Ace-EFc on $\mathrm{H}_{2} \mathrm{O}_{2}$-induced cytotoxicity, HaCaT cells were initially treated with Ace-EFc as described previously. The medium was discarded, and subsequently, cells were treated with $\mathrm{H}_{2} \mathrm{O}_{2}$ (1000 $\mu \mathrm{M}$ for $2 \mathrm{~h}$ ) according to the model established $\mathrm{H}_{2} \mathrm{O}_{2}$-induced cytotoxicity. The percentage of viable cells was determined by the following formula:

$$
\text { Viable cells }=\left(\frac{\mathrm{A} b \text { Sample }}{\mathrm{A} b \text { Blank }}\right) \times 100
$$

\subsection{Oxidative Damage Determination (Lipoperoxidation)}

$\mathrm{HaCaT}$ cells were grown in a six-well plate to $80 \%$ confluence and were treated with $0-20 \mu \mathrm{g} / \mathrm{mL}$ of Ace-EFc for $24 \mathrm{~h}$. Later, the medium was discarded, and subsequently, cells were treated with $\mathrm{H}_{2} \mathrm{O}_{2}\left(1000 \mu \mathrm{M}\right.$ for $2 \mathrm{~h}$ ), according to the model established $\mathrm{H}_{2} \mathrm{O}_{2}$ induced cytotoxicity. The supernatant was recovered $(2 \mathrm{~mL})$, and the cells were trypsinized and resuspended in $65 \mu \mathrm{L}$ PBS (pH 7.4), and vortexed for $1 \mathrm{~min}$. To quantify MalonDiAldehyde (MDA) levels, $50 \mu \mathrm{L}$ of the sample (supernatant or cells separately), $50 \mu \mathrm{L}$ Milli $\mathrm{Q}$ water, $350 \mu \mathrm{L}$ MPI (1-Methyl-2-OhenylIndole) reagent $(10 \mathrm{mM})$, and $100 \mu \mathrm{L} \mathrm{HCl}(37 \%)$ were mixed, shaken, and they were incubated for $40 \mathrm{~min}$ at $45^{\circ} \mathrm{C}$. They were subsequently centrifuged at $4{ }^{\circ} \mathrm{C}$ at $7000 \mathrm{rpm}$ for $10 \mathrm{~min}$ and the absorbance was read at $586 \mathrm{~nm}$ (NanoDrop 2000, Waltham, MA, USA) [46]. The data were normalized with the total protein concentration of each sample obtained by the Bradford assay. The final concentration of MDA in each sample was obtained by adding the data obtained from both the supernatant and the cell suspension.

\subsection{Statistical Analysis}

Data analysis was performed using GraphPad Prism version 6.0 statistical software. The data were shown as the mean \pm standard deviation (SD). One-way analysis of variance (ANOVA) was used with the Dunnett multiple comparison test. Statistically significant differences were considered when $p<0.05$.

Supplementary Materials: The following are available online at https:/ /www.mdpi.com/2223-774 7/10/1/183/s1, Figure S1. GC-MS analysis of acetone extract of Ficus crocata (Miq.) Mart. ex Miq. leaves. Figure S2: Antiradical activity of Ace-EFc.

Author Contributions: Conceptualization: M.A.M.-C. and M.E.-R.; methodology, B.D.1.C.-C., M.E.R., P.Á.-F., M.A.-Q., A.E.Z.-G., F.I.T.-R., and H.J.-W.; validation: M.A.M.-C., M.E.-R., N.N.-T., and B.I.-A.; formal analysis: B.D.l.C.-C., F.I.T.-R. and M.A.-Q.; investigation: B.D.l.C.-C., M.E.-R., and A.E.Z.-G.; resources: M.A.M.-C., M.E.-R., and B.I.-A.; data curation: M.A.M.-C., P.Á.-F., and M.E.R.; writing —original draft preparation: B.D.l.C.-C. and M.A.M.-C.; writing-review and editing: M.A.M.-C., M.E.-R., and B.I--A.; supervision, M.A.M.-C. and M.E.-R.; project administration: M.A.M.C. and M.E.-R.; funding acquisition, M.A.M.-C. All authors have read and agreed to the published version of the manuscript.

Funding: This research was funded by Universidad Autónoma de Guerrero, grant SEMILLA 2018. The APC was funded partially by Universidad Autónoma de Guerrero.

Institutional Review Board Statement: Not applicable.

Informed Consent Statement: Not applicable.

Data Availability Statement: The data presented in this study are available within the article and its supplementary material.

Acknowledgments: B.D.1.C.-C. received a postgraduate Master's degree fellowship from the National Council of Science and Technology (CONACYT-México).

Conflicts of Interest: The authors declare no conflict of interest. 


\section{References}

1. Rahal, A.; Kumar, A.; Singh, V.; Yadav, B.; Tiwari, R.; Chakraborty, S.; Dhama, K. Oxidative stress, prooxidants, and antioxidants: The interplay. BioMed Res. Int. 2014. [CrossRef] [PubMed]

2. Chen, X.; Song, M.; Zhang, B.; Zhang, Y. Reactive oxygen species regulate $\mathrm{T}$ cell immune response in the tumor microenvironment. Oxidative Med. Cell. Longev. 2016. [CrossRef] [PubMed]

3. Biswas, S.K. Does the interdependence between oxidative stress and inflammation explain the antioxidant paradox? Oxidative Med. Cell. Longev. 2016. [CrossRef]

4. Zi, Y.; Zhang, B.; Jiang, B.; Yang, X.; Liang, Z.; Liu, W.; He, C.; Liu, L. Antioxidant action and protective and reparative effects of lentinan on oxidative damage in HaCaT cells. J. Cosmet. Dermatol. 2018, 17, 1108-1114. [CrossRef]

5. Kumari, A.; Kakkar, P. Lupeol prevents Acetaminophen-induced in vivo hepatotoxicity by altering the Bax/Bcl-2 and oxidative stress-mediated mitochondrial signaling cascade. Life Sci. 2012, 90, 561-570. [CrossRef] [PubMed]

6. Yamaguchi, E.; Tsuchiya, M.; Shimamoto, S.; Fujimoto, T.; Tokumitsu, H.; Tokuda, M. Oxidative stress impairs the stimulatory effect of S100 proteins on protein phosphatase 5 activity. Tohoku J. Exp. Med. 2016, 240, 67-78. [CrossRef]

7. Hecht, F.; Pessoa, C.F.; Gentile, L.B.; Rosenthal, D.; Carvalho, D.P.; Fortunato, R.S. The role of oxidative stress on breast cancer development and therapy. Tumour Biol. 2016, 37, 4281-4291. [CrossRef]

8. Gupta, A.K.; Rather, M.A.; Kumar Jha, A.; Shashank, A.; Singhal, S.; Sharma, M.; Pathak, U.; Sharma, D.; Mastinu, A. Artocarpus lakoocha Roxb. and Artocarpus heterophyllus Lam. Flowers: New Sources of Bioactive Compounds. Plants 2020, 9, 1329. [CrossRef]

9. Mopuri, A.; Ganjayi, M.; Meriga, B.; Koorbanally, N.A.; Islam, M.S. The effects of Ficus carica on the activity of enzymes related to metabolic syndrome Ramgopal. J. Food Drug Anal. 2018, 26, 201-210. [CrossRef]

10. Nurdiana, S.; Goh, Y.M.; Ahmad, H.; Dom, S.M.; Syimal'ain, N.; Noor Mohamad Zin, N.S.; Ebrahimi, M. Changes in pancreatic histology, insulin secretion and oxidative status in diabetic rats following treatment with Ficus deltoidea and vitexin. BMC Complement. Altern. Med. 2017, 17, 290. [CrossRef]

11. Joshi, H.; Vaishnav, D.; Sanghvi, G.; Rabadia, S.; Airao, V.; Sharma, T. Ficus recemosa bark extract attenuates diabetic complications and oxidative stress in STZ-induced diabetic rats. Pharm. Biol. 2016, 54, 1586-1595. [CrossRef] [PubMed]

12. Sumi, S.A.; Siraj, M.A.; Hossain, A.; Mia, M.S.; Afrin, S.; Rahman, M.M. Investigation of the key pharmacological activities of Ficus racemosa and analysis of its major bioactive polyphenols by HPLC-DAD. Evid. Based Complement. Altern. Med. 2016. [CrossRef] [PubMed]

13. Ibarra-Manríquez, G.; Cornejo-Tenorio, G.; González-Castañeda, N.; Piedra-Malagón, E.M.; Luna, A. El género Ficus L. (Moraceae) en México. Bot. Sci. 2012, 90, 389-452. [CrossRef]

14. Saba, N.F.; Mody, M.D.; Tan, E.S.; Gill, H.S.; Rinaldo, A.; Takes, R.P.; Strojan, P.; Hartl, D.M.; Vermorken, J.B.; Haigentz, M., Jr.; et al. Toxicities of systemic agents in squamous cell carcinoma of the head and neck (SCCHN); A new perspective in the era of immunotherapy. Crit. Rev. Oncol. Hematol. 2017, 115, 50-58. [CrossRef] [PubMed]

15. Sánchez-Valdeolivar, C.A.; Álvarez-Fitz, P.; Zacapala-Gómez, A.E.; Acevedo-Quiroz, M.; Cayetano-Salazár, L.; Olea-Flores, M.; Castillo-Reyes, J.U.; Navarro-Tito, N.; Ortuño-Pineda, C.; Leyva-Vázquez, M.A.; et al. Phytochemical profile and antiproliferative effect of Ficus crocata extracts on triple-negative breast cancer cells. BMC Complement. Med. Ther. 2020, 20, 1-15. [CrossRef]

16. Gupta, N.; Verma, K.; Nalla, S.; Kulshreshtha, A.; Lall, R.; Prasad, S. Free Radicals as a Double-Edged Sword: The Cancer Preventive and Therapeutic Roles of Curcumin. Molecules 2020, 25, 5390. [CrossRef] [PubMed]

17. Wang, M.; Li, J.; Rangarajan, M.; Shao, Y.; LaVoie, E.J.; Huang, T.C. Antioxidative phenolic compounds from sage (Salvia officinalis). J. Agric. Food Chem. 1998, 46, 4869-4873. [CrossRef]

18. Cerretani, L.; Bendini, A. Olives and Olive Oil in Health and Disease Prevention, 1st ed.; Academic Press: San Diego, CA, USA, 2010.

19. Adebiyi, O.E.; Funsho, O.O.; Ning-Hua, T.; Guang-Zhi, Z. In vitro antioxidant activity, total phenolic and flavonoid contents of ethanol extract of stem and leaf of Grewia carpinifolia. Beni Suef Univ. J. Appl. Sci. 2017, 6, 10-14. [CrossRef]

20. Zervos, I.A.; Nikolaidis, E.; Lavrentiadou, S.N.; Tsantarliotou, M.P.; Eleftheriadou, E.K.; Papapanagiotou, E.P.; Fletouris, D.J.; Georgiadis, M.; Taitzoglou, I.A. Endosulfan-induced lipid peroxidation in rat brain and its effect on t-PA and PAI-1: Ameliorating effect of vitamins C and E. J. Toxicol. Sci. 2011, 36, 423-433. [CrossRef]

21. Sun, Y.; Zhou, C.; Huang, S.; Jiang, C. Selenium polysaccharide SPMP-2a from Pleurotus geesteranus alleviates $\mathrm{H}_{2} \mathrm{O}_{2}$-induced oxidative damage in HaCaT cells. BioMed Res. Int. 2017. [CrossRef]

22. Xiao, X.; Liu, J.; Hu, J.; Zhu, X.; Yang, H.; Wang, C.; Zhang, Y. Protective effects of protopine on hydrogen peroxide-induced oxidative injury of PC12 cells via Ca( $\left.2^{+}\right)$antagonism and antioxidant mechanisms. Eur. J. Pharmacol. 2008, 591, 21-27. [CrossRef] [PubMed]

23. Yoon, J.J.; Jeong, J.W.; Choi, E.O.; Kim, M.J.; Hwang-Bo, H.; Kim, H.J.; Hong, S.H.; Park, C.; Lee, D.H.; Choi, Y.H. Protective effects of Scutellaria baicalensis Georgi against hydrogen peroxide-induced DNA damage and apoptosis in HaCaT human skin keratinocytes. EXCLI J. 2017, 16, 426-438. [CrossRef] [PubMed]

24. Chen, Z.; Wang, C.; Yu, N.; Si, L.; Zhu, L.; Zeng, A.; Liu, Z.; Wang, X. INF2 regulates oxidative stress-induced apoptosis in epidermal HaCaT cells by modulating the HIF1 signaling pathway. Biomed. Pharmacother. 2019, 111, 151-161. [CrossRef] [PubMed]

25. Yoon, Y.; Lee, Y.M.; Song, S.; Lee, Y.Y.; Yeum, K.J. Black soybeans protect human keratinocytes from oxidative stress-induced cell death. Food Sci. Nutr. 2018, 6, 2423-2430. [CrossRef] [PubMed] 
26. Fuhrmann, D.C.; Brüne, B. Mitochondrial composition and function under the control of hypoxia. Redox Biol. 2017, 12, $208-215$. [CrossRef]

27. Zhou, H.; Shi, C.; Hu, S.; Zhu, H.; Ren, J.; Chen, Y. BI1 is associated with microvascular protection in cardiac ischemia reperfusion injury via repressing Syk-Nox2-Drp1-mitochondrial fission pathways. Angiogenesis 2018, 21, 599-615. [CrossRef] [PubMed]

28. Zhou, H.; Wang, J.; Zhu, P.; Zhu, H.; Toan, S.; Hu, S.; Ren, J.; Chen, Y. NR4A1 aggravates the cardiac microvascular ischemia reperfusion injury through suppressing FUNDC1-mediated mitophagy and promoting Mff-required mitochondrial fission by CK2alpha. Basic Res. Cardiol. 2018, 113, 23. [CrossRef]

29. Zhu, H.; Jin, Q.; Li, Y.; Ma, Q.; Wang, J.; Li, D.; Zhou, H.; Chen, Y. Melatonin protected cardiac microvascular endothelial cells against oxidative stress injury via suppression of IP3R-[Ca $\left.{ }^{2+}\right] \mathrm{c} / \mathrm{VDAC}-\left[\mathrm{Ca}^{2+}\right] \mathrm{m}$ axis by activation of MAPK/ERK signaling pathway. Cell Stress Chaperones 2018, 23, 101-113. [CrossRef]

30. Perona, J.S.; Cabello-Moruno, R.; Ruiz-Gutierrez, V. The role of virgin olive oil components in the modulation of endothelial function. J. Nutr. Biochem. 2006, 17, 429-445. [CrossRef]

31. Wu, T.K.; Pan, Y.R.; Wang, H.F.; Wei, C.W.; Yu, Y.L. Vitamin E ( $\alpha$-tocopherol) ameliorates aristolochic acid-induced renal tubular epithelial cell death by attenuating oxidative stress and caspase3 activation. Mol. Med. Rep. 2018, 17, 31-36. [CrossRef]

32. Adebiyi, O.E.; Olayemi, F.O.; Olopade, J.O.; Tan, N.H. Beta-sitosterol enhances motor coordination, attenuates memory loss and demyelination in a vanadium-induced model of experimental neurotoxicity. Pathophysiology 2018, 26, 21-29. [CrossRef] [PubMed]

33. Suriyakalaa, U.; Ramachandran, R.; Usha, K.; Sankarganesh, D.; Praveenkumar, D.; Abinaya, S.; Tirupathi Pichiah, P.B.; Kamalakkannan, S.; Achiraman, S. Squalene is a potential endocrine modulator in rat: A proof-of-principle study with 3methylcholanthrene-induced toxicity. Andrologia 2018, 50, e13117. [CrossRef] [PubMed]

34. Kumari, A.; Kakkar, P. Lupeol protects against acetaminophen induced oxidative stress and cell death in rat primary hepatocytes. Food Chem. Toxicol. 2012, 50, 1781-1789. [CrossRef] [PubMed]

35. Jamilian, M.; Hashemi Dizaji, S.; Bahmani, F.; Taghizadeh, M.; Memarzadeh, M.R.; Karamali, M.; Akbari, M.; Asemi, Z. A randomized controlled clinical trial investigating the effects of omega-3 fatty acids and vitamin E co-supplementation on biomarkers of oxidative stress, inflammation and pregnancy outcomes in gestational diabetes. Can. J. Diabetes 2017, 41, 143-149. [CrossRef] [PubMed]

36. Schneider, C. Chemistry and biology of vitamin E. Mol. Nutr. Food Res. 2005, 49, 7-30. [CrossRef] [PubMed]

37. Milczarek, R.; Klimek, J.; Zelewski, L. The effects of ascorbate and alpha-tocopherol on the NADPH-dependent lipid peroxidation in human placental mitochondria. Mol. Cell. Biochem. 2000, 210, 65-73. [CrossRef]

38. Brimson, J.M.; Brimson, S.J.; Brimson, C.A.; Rakkhitawatthana, V.; Tencomnao, T. Rhinacanthus nasutus extracts prevent glutamate and amyloid- $\beta$ neurotoxicity in HT-22 mouse hippocampal cells: Possible active compounds include lupeol, stigmasterol and $\beta$-sitosterol. Int. J. Mol. Sci. 2012, 13, 5074-5097. [CrossRef]

39. Papi Reddy, K.; Singh, A.B.; Puri, A.; Srivastava, A.K.; Narender, T. Synthesis of novel triterpenoid (lupeol) derivatives and their in vivo antihyperglycemic and antidyslipidemic activity. Bioorg. Med. Chem. Lett. 2009, 19, 4463-4466. [CrossRef]

40. Takhshid, M.A.; Tavasuli, A.R.; Heidary, Y.; Keshavarz, M.; Kargar, H. Protective effect of vitamins E and C on endosulfan-induced reproductive toxicity in male rats. Iran. J. Med. Sci. 2012, 37, 173-180.

41. Kim, W.S.; Kim, I.; Kim, W.K.; Choi, J.Y.; Kim, D.Y.; Moon, S.G. Mitochondria-targeted vitamin E protects skin from UVBirradiation. Biomol. Ther. 2016, 24, 305-311. [CrossRef]

42. Wu, T.K.; Wei, C.W.; Pan, Y.R.; Cherng, S.H.; Chang, W.J.; Wang, H.F.; Yu, Y.L. Vitamin C attenuates the toxic effect of aristolochic acid on renal tubular cells via decreasing oxidative stress-mediated cell death pathways. Mol. Med. Rep. 2015, 12, 6086-6092. [CrossRef] [PubMed]

43. Sudhahar, V.; Veena, C.K.; Varalakshmi, P. Antiurolithic effect of lupeol and lupeol linoleate in experimental hyperoxaluria. J. Nat. Prod. 2008, 71, 1509-1512. [CrossRef] [PubMed]

44. Sulaiman, S.F.; Ooi, K.L. Polyphenolic and vitamin C contents and antioxidant activities of aqueous extracts from mature-green and ripe fruit fleshes of Mangifera sp. J. Agric. Food Chem. 2012, 60, 11832-11838. [CrossRef]

45. Re, R.; Pellegrini, N.; Proteggente, A.; Pannala, A.; Yang, M.; Rice, C. Antioxidant activity applying an improved ABTS radical cation decolorization assay. Free Radic. Biol. Med. 1999, 26, 1231-1237. [CrossRef]

46. Siddique, Y.H.; Ara, G.; Afzal, M. Estimation of lipid peroxidation induced by hydrogen peroxide in cultured human lymphocytes. Dose Response 2012, 10, 1-10. [CrossRef] [PubMed] 